$$
\text { . }
$$




$$
\text { . }
$$




\section{"Sønderjydske Aarbøger"}

\section{udgivno af}

\section{F. P. F̧anssen-Norremolle, P. Skau og Nikolaj findersen}

begyndte at udkomme 18s!) og "hat siden $\mathrm{j}$ on Raklie forskellign Bidlag skildret Slesvirs Historie, Land. Folk og Minder og har i politiske og statistiske oversinter bryst Nordslesvigernes Kamp for Bevalelsen af dansk Sproge og Kultur.

,Nonderjydske Aarboger.6 vil som hidtil behaulle? allo nordslesvigske Sporgsmaal i videste Omfang, Historie oy Politik, Sprogr og Folkeminder, Naturforloble og Lamdokononi. De vil desuden lringe Skildringer af andre Nationalitetskampei Fortid og Nutid og Iroftelse af sadanne Forhold, der dirrkte eller indirekte statar i Forbindelse dermed.

, Sonderjydske Aarboger66 udkommer to (tange a arligt i Haftrer paa tilsammun ontr. 20 Ark. Subskription moltages i alle Buplader i Slesrigr, Danmark, Norge og Sverige ou i Gyldendalske Bourhandel, Horedkommissimen for de tre nordiske Lande. Prisen er 4 Kroner Aargangen; for Medlemmer af danske Foreninger i Nordslesviy 3 Mark.

\section{Indhold of I. Falubind 1914.}

Kr. Kefslund Thomsen: (1knnomiske Organisationer....... . Side $1-4 i$

M. Refslund Poulsen: Nybyggerforeningen for det vestliga slesvig. . . " 4Y-ift

H. P. H a ns se n-N a rrem u l le : De danske.

Nikulajerjyder andersen: De prijaiske Lamldagsvalg i Nordsle,vig.

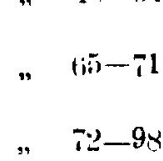

